\title{
Grazing and UV radiation effects on an Antarctic intertidal microalgal assemblage: a long-term field study
}

\author{
Katharina Zacher · Dieter Hanelt · Christian Wiencke • \\ Angela Wulff
}

Received: 13 November 2006/Revised: 22 February 2007 / Accepted: 3 March 2007

(C) Springer-Verlag 2007

\begin{abstract}
A 15 week field experiment (austral summer Nov-Mar) was carried out in an intertidal hard bottom platform in Antarctica (King George Island). To test whether grazing and ultraviolet radiation (UVR) influenced the succession of a benthic microalgal assemblage, a twofactorial design was used (1) ambient radiation, $>280 \mathrm{~nm}$; (2) ambient minus UV-B, $>320 \mathrm{~nm}$; (3) ambient minus UVR, $>400 \mathrm{~nm}$ versus grazer-no grazer). On four sampling occasions microalgae were identified, counted and carbon contents were calculated. The assemblage was dominated by the diatom genera Navicula and Cocconeis. Biomass was generally low in all treatments but was significantly reduced by grazing throughout the experiment. No significant UV effects were found. Grazer absence particularly favoured diatoms of the genus Cocconeis. We conclude that the Antarctic microalgal assemblage was unaffected by present day UVR whereas grazers acted as important drivers on the intertidal microalgal community structure.
\end{abstract}

Keywords Benthic diatoms - Diversity - Grazing · Hard bottom community - Microalgae · UV radiation

K. Zacher $(\bowtie) \cdot$ C. Wiencke

Alfred Wegener Institute for Polar and Marine Research, Am Handelshafen 12, 27570 Bremerhaven, Germany e-mail: Katharina.Zacher@awi.de

D. Hanelt

Biozentrum Klein Flottbek, University of Hamburg, Ohnhorststr. 18, 22609 Hamburg, Germany

A. Wulff

Department of Marine Ecology, Göteborg University, P.O. Box 461, 40530 Göteborg, Sweden

\section{Introduction}

Benthic microalgal communities, on hard and soft bottom substrata, are of vital importance for the ecological function in marine habitats. They constitute the local basis of the food webs in shallow areas, which are recognized to have a high secondary production (e.g., of fish and fish prey; Villafañe et al. 2003). The benthic heterotrophic community is depending on a sufficient primary production. However, in polar areas only a minor fraction of the gross pelagic primary production reaches the sediment, due to efficient carbon and nutrient recycling in the upper water column (e.g., Rysgaard et al. 1999). The importance of benthic microalgae for ecosystem primary production on a global scale based on 85 worldwide studies was reviewed by Cahoon (1999). Of these, only four studies were performed in polar regions. In Antarctic coastal ecosystems, poor development of pelagic microalgae (Hapter et al. 1983; Schloss et al. 1998), but an important contribution of resuspended benthic diatoms to the phytoplankton have been suggested and/or observed (e.g., Ahn et al. 1994; Gilbert 1991a, b). In the Arctic, a detailed study of carbon cycling in a fjord system showed that the primary production of phytoplankton and ice algae could not account for the carbon input required by the benthic community (Glud et al. 2000; Rysgaard et al. 2001). Thus, benthic microalgae are likely to provide an important food source for both benthic and pelagic heterotrophs.

The Antarctic "ozone hole" and the consequent increase of UV-B radiation (280-320 nm), is a well-known fact and despite efforts to minimize the anthropogenic impact on stratospheric ozone destruction little improvement is expected for total column ozone in the Antarctic for decades (Weatherhead and Andersen 2006). One reason 
is that many factors influencing ozone levels (e.g., carbon dioxide emission, stratospheric temperature and circulation patterns), are also changing, and even if the anthropogenic impact in terms of ozone depleting compounds were removed, the ozone levels might never reach pre-1980 values (Weatherhead and Andersen 2006). It is therefore of high interest to study the impact of UV radiation on the Antarctic ecosystem, particularly important primary producers such as microalgae.

In the present study, UV-B radiation penetrated down to $16 \mathrm{~m}$ ( $1 \%$ of surface intensity). Thus, the tidal microalgal assemblages were exposed to high irradiances of both photosynthetic active radiation (PAR, 400-700 nm) and UV-B radiation. There are basically two ways for the microorganisms to react to UV-B radiation: adaptation or avoidance. Adaptation processes include protection and repair mechanisms. Avoidance of UV-B includes the ability to move away from the harmful radiation (Underwood et al. 1999), and on community level, "selfshading" i.e., cells deeper in the assemblages get protection through light absorption by cells at the surface (Blanchard and Gall 1994). In a hard bottom microphytobenthic community the adaptation processes are more important because a movement deeper into the sediment is not possible.

The complexity of links-trophic and non-trophicinherent in most natural systems (Polis and Strong 1996), makes it difficult to interpret treatment effects in natural experimental systems. However, the more we study intact communities under different environmental conditions, in addition to mechanistic experiments to identify certain key mechanisms, the closer we get to an understanding of what is happening in complex communities. Thus, short-term experiments could give an insight about the worst-case scenario for UV radiation effects on, e.g., photosynthesis but long-term studies under ambient radiation are more ecologically relevant (Wulff et al. 1999; Zacher et al. 2007).

Field experiments about the UV radiation impact on microalgal community structure are scant in general, but even more in Antarctica (but see Wahl et al. 2004). Studies on the interactive effects of herbivory and UV radiation considering successional processes of benthic microalgae are to our knowledge completely missing for Antarctic communities (see Bothwell et al. 1994 for temperate regions).

In the present study, the succession of an intertidal microalgal community in Antarctica was investigated in a field experiment to answer the questions: (1) how UV radiation and grazers influence biomass and abundance of a field-grown microalgal assemblage and (2) whether there are any interactive effects of UV radiation and grazers on the microalgal assemblage structure.

\section{Materials and methods}

Study site

The field experiment was conducted at a rocky intertidal platform at Peñón Uno, King George Island, Antarctica $\left(62^{\circ} 14^{\prime} \mathrm{S}, 58^{\circ} 41^{\prime} \mathrm{W}\right)$. Common grazers at the study site are the gastropod Nacella concinna Strebel and other, smaller gastropods like Laevilacunaria antarctica Martens and Laevilitorina umbilicata Pfeffer (Iken 1996). Dominant amphipod species in the area are Gondogeneia antarctica Chevreux and Djerboa furcipes Chevreux (Jazdzewski et al. 2001; Obermüller personal communication). During the sampling period, the maximal tidal range was ca. $2 \mathrm{~m}$ and the sea surface temperature ranged between $-1.8^{\circ} \mathrm{C}$ (spring), and $2^{\circ} \mathrm{C}$ (summer). UV-transparency of the water body is highest in spring decreasing with higher temperatures due to the entrance of glacial freshwater and sediment. Minimum concentrations of nitrate, phosphate, and silicate were previously recorded in February at non-limiting algal growth levels of 15,2 and $47 \mu \mathrm{M}$, respectively (Schloss et al. 2002).

\section{Experimental design and set-up}

Using a randomized block design, we tested in a two-factorial experiment the effects of grazers (two levels, fixed) and UV radiation (three levels, fixed) on the succession of a microalgal assemblage $(n=4)$. The experiment was run from 28 November 2004 to 14 March 2005 (106 days). A pilot-study was performed from 20 December 2003 to 9 March 2004 (74 days). Results from both years were similar, therefore, only data from the second longer experiment are shown here. Thirty-two PVC cages $(50 \times 50 \times 12 \mathrm{~cm}, n=4$, including eight control treatments) were fixed to the substratum in the lower eulittoral at a minimal distance of $1 \mathrm{~m}$ to each other. Cages were submerged at a maximum depth of $2 \mathrm{~m}$ during highest tide levels or exposed during lowest tide levels. Cages were either open to all sides (open cage) or closed with plastic mesh (1 mm mesh size) to exclude macrograzers (closed cage). To test for cage artefacts, partially open cages (half cages, equipped with PAB filters, see below, $n=4$ ) were deployed by cutting two holes $(\sim 5 \times 5 \mathrm{~cm}=25 \%)$, into each sidewall. Using cut-off filters as cage tops, ambient UV radiation levels were manipulated (see below for details). Open cages without filter ( $=$ full sunlight, $n=4$ ), were used as procedural controls to test for filter artefacts. Unglazed ceramic tiles served as settlement substrata and were attached with Velcro to cage bottoms. Each cage contained four large $(10 \times 10 \mathrm{~cm})$ and eight small tiles $(5 \times 5 \mathrm{~cm})$. At each of four sampling events, one small tile was randomly withdrawn from each cage to determine 
treatment effects on the microalgal community. The other tiles were used to detect treatment effects on the macroalgal community (Zacher et al. 2007).

\section{$\mathrm{UV}$ radiation treatments}

Cut-off filters manipulated the ambient light regime in three ways (Fig. 1). (1) P = PAR (photosynthetically active radiation, $>400 \mathrm{~nm}$ ): using a $3 \mathrm{~mm}$ thick Plexiglas sheet (GS 231, Röhm, Germany), radiation $<400 \mathrm{~nm}$ was blocked, while filters were transparent for $91 \%$ of PAR. (2) $\mathrm{PA}=\mathrm{PAR}+\mathrm{UV}-\mathrm{A}(>320 \mathrm{~nm}):$ using a $3 \mathrm{~mm}$ thick Plexiglas sheet (GS 2458, Röhm, Germany) and a $0.13 \mathrm{~mm}$ transparent polyester film (Folanorm-SF/AS, folex imaging $\mathrm{GmbH}$, Germany), radiation $<320 \mathrm{~nm}$ was blocked, while $89 \%$ of PAR and UV-A passed the filter. (3) $\mathrm{PAB}=$ PAR + UV-A + UV-B (> $280 \mathrm{~nm})$ : using a $3 \mathrm{~mm}$ thick Plexiglas sheet (GS 2458, Röhm, Germany) transmitting $92 \%$ of PAR and UV radiation. Transparency of the GS 231 and GS 2458 Plexiglas filters decreased on average by $1.11 \%(\mathrm{SD} \pm 0.01)$ and $1.31 \%(\mathrm{SD} \pm 0.01)$ per month, respectively. Therefore only damaged filters were exchanged. Polyester films were exchanged bi-weekly to minimize aging and fouling effects on transparency. Filters were cleaned once or twice per week.

\section{Radiation measurements}

Weekly to bi-weekly, the radiation regime above the water surface, at 10 and $200 \mathrm{~cm}$ depth was recorded at a distance $\sim 50 \mathrm{~m}$ to the experimental site with a LiCor data logger (LI-1400, Li-Cor, Lincoln, USA) equipped with an underwater PAR sensor (LI-192), and a Solar Light

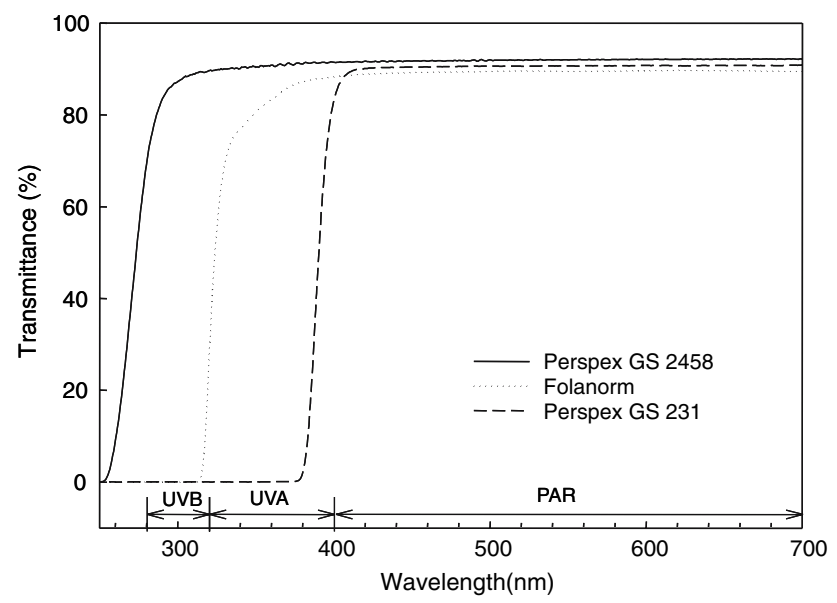

Fig. 1 Optical properties of cut-off filters for the different UV treatments: (1) Perspex GS $2458=$ PAR + UV-A + UV-B, (2) Perspex GS $2458+$ Folanorm $=$ PAR + UV-A, and (3) Perspex GS 231 = PAR only
(PMA2100, Solar Light Co. Inc., USA), equipped with a UV-B (PMA2106-UW), and a UV-A radiation (PMA2110$\mathrm{UW})$, broad-band sensor. Readings were taken $\pm 1 \mathrm{~h}$ of local noon. Ambient UV-A + UV-B, radiation was continuously recorded at the nearby $(1.5 \mathrm{~km})$, Dallmann Laboratory with a 32-channel single-quantum counting spectroradiometer (Isitec, Germany). In addition, the weighted irradiance (minimal erythemal dose, $U_{\text {ery }}$ ), was measured continuously next to the cages with two ELUV14 UV-dosimeters (El Naggar et al. 1995), to follow the relative changes of the underwater UV-B regime during the experiment.

Diffuse vertical attenuation coefficient of downward irradiance $\left(K_{\mathrm{d}}\right)$ was determined using the following formula (after Kirk 1994): $K_{\mathrm{d}}=\ln \left[\operatorname{Ed}_{(z 2)} / \operatorname{Ed}_{(z 1)}\right] \times\left(z_{1}-z_{2}\right)^{-1}$

$\operatorname{Ed}_{(z 1)}$ and $\operatorname{Ed}_{(z 2)}$ are the respective irradiances at depth $z_{1}(0.1 \mathrm{~m})$ and $z_{2}(2 \mathrm{~m})$.

\section{Grazer abundance}

Macrobenthic grazer density in each cage was estimated in January and March 2005 (by SCUBA diving). In each cage, the individuals of each gastropod species were counted and the density of amphipods estimated in categories of tens. Grazers inside closed cages were also counted and occasionally captured gastropods were removed. Amphipods entering or recruiting in the closed cages could not be removed and remained inside.

\section{Sampling of microalgae}

Sampling of the microalgal assemblage on the tiles occurred on 10 January, 7 and 24 February, and 14 March 2005 (i.e., 43, 71, 88, and 106 days after starting the experiment). Tiles were brought to the laboratory, immediately frozen $\left(-20^{\circ} \mathrm{C}\right)$ and brought to Göteborg, Sweden for further analysis. Microalgae were sampled and resuspended in $2.5 \%$ glutaraldehyde. After shaking each sample for $20 \mathrm{~s}$ a $20 \mu \mathrm{l}$ subsample was put on an object slide and cell numbers were counted until a total of 300 cells under a known number of light fields in the microscope (various subsamples were used for each sample). Cells were counted in different size classes. Seven size classes of frequently found species were chosen according to their size and genus: (1) naviculoid cells $<12.5 \mu \mathrm{m}$, (2) naviculoid cells $>12.5 \mu \mathrm{m}$, (3) Cocconeis < $25 \mu \mathrm{m}$, (4) Cocconeis $>25 \mu \mathrm{m}$, (5) Licmophora narrow, (6) Licmophora broad, (7) Fragilariopsis. All of these groups were found in almost all counted subsamples. The diatom genus Cocconeis was affected by freezing of the tiles (for conservation), sometimes causing cell ruptures. This was taken into consideration while counting. 
Microalgal biomass

For conversion to carbon, averaged cell volumes were calculated by measuring biovolumes for each size class (in $\mu \mathrm{m}^{3}$ ) and multiplying it with a factor of $10^{-12} \times$ $0.089 \mathrm{~g} \mathrm{C} \mathrm{cell}^{-1}$ (Edler 1979). For calculating biovolumes, cell dimensions of a minimum of 30 cells per species or size classes and per light treatment were measured and average cell volumes calculated from geometric formula (Edler 1979; Hillebrand et al. 1999).

\section{Species identification}

Naphrax mounted slides were prepared for diatom species identification. Samples were washed with distilled water to remove the salts and then boiled with $30 \% \mathrm{H}_{2} \mathrm{O}_{2}$ to remove organic matter. Approximately, 1-2 drops of $50 \% \mathrm{HCl}$ were added to remove carbonates and to eliminate $\mathrm{H}_{2} \mathrm{O}_{2}$. After washing, diatom suspensions were allowed to settle on a cover slip and left to dry before mounted. For species identification, differential interference contrast and phase contrast microscopy $(100 \times$ magnification $)$ were used (Axioplan 2 imaging, Zeiss, Germany). Diatoms were identified following Hustedt (1961-1966), Krammer and Lange-Bertalot $(1986,1988)$, Hendey $(1952,1964)$ and Witkowski et al. (2000). The nomenclature was updated with the help of Round et al. (1990).

\section{Data analysis}

A $t$ - test was performed to test for differences between two independent groups (e.g., test for cage or filter artefacts). For separate sampling dates, a two-way ANOVA was performed to test for the effects of consumers and UV radiation on density (number $\mathrm{m}^{-2}$ ) and carbon content at a Bonferroni corrected significance level $(\alpha=0.0125)$, in order to lower the probability of making a type I error (Quinn and Keough 2004). Prior to analysis, data were tested for homogeneity of variances (Cochran's test). Heteroscedastic data after ln- or square-root transformation were analyzed by the non-parametric Kruskal-Wallis test. Post-hoc comparisons were performed with NewmanKeuls test using Statistica ${ }^{\text {TM }} 6.0$ software package. Species composition of communities was compared by ANOSIM, and in case of significance, followed by SIMPER to quantify the relative contribution of species to observed dissimilarities among treatments (PRIMER ${ }^{\mathrm{TM}} 5$ software package, Plymouth Marine Laboratory). ANOSIM used a Bray-Curtis similarity matrix based on root transformed density data.

\section{Results}

UV measurements

Figure 2 shows the daily doses of UV-A and UV-B radiation measured during December 2004 and April 2005. Peak values of UV-A and UV-B radiation (air) were recorded in December, coinciding with the highest values of underwater UV-B irradiance determined as $\mathrm{UV}_{\text {ery }}$ (Fig. 3). Lowest underwater UV-B values during the experiment were measured in February and March 2005 (Fig. 3). Maximum UV exposure on the tiles was reached during low tide on the 14th of December 2004 (around noon), were the cages were fully exposed to $44 \mathrm{~W} \mathrm{~m}^{-2} \mathrm{UV}-\mathrm{A}$ and $2.3 \mathrm{~W} \mathrm{~m}^{-2} \mathrm{UV}-\mathrm{B}$, respectively (irradiance in air). Table 1 shows the minimal and maximal values measured with a broadband sensor at the experimental site during the experiment. The depth range between 10 and $200 \mathrm{~cm}$ water depth covers the range from very high tide to almost low tide. Maximal values were encountered in December/January and minimal in February.

\section{Grazer abundance}

In January and March, gastropod densities in open and half cages showed no significant differences (January: $t$ test $=2.41, P>0.05$; March: $t$ test $=1.62, P>0.05)$, thus no cage artefact was observed. Gastropod densities in closed cages were significantly lower in comparison to open cages in January $(t$ test $=6.20, P<0.001)$ and equal in March ( $t$ test $=1.79, P>0.05)$. The gastropod $N$. concinna was successfully excluded from the closed cages throughout the experiment (Table 2).

Amphipod density in January and March was higher in half cages $(n=4)$, than in open cages (January:

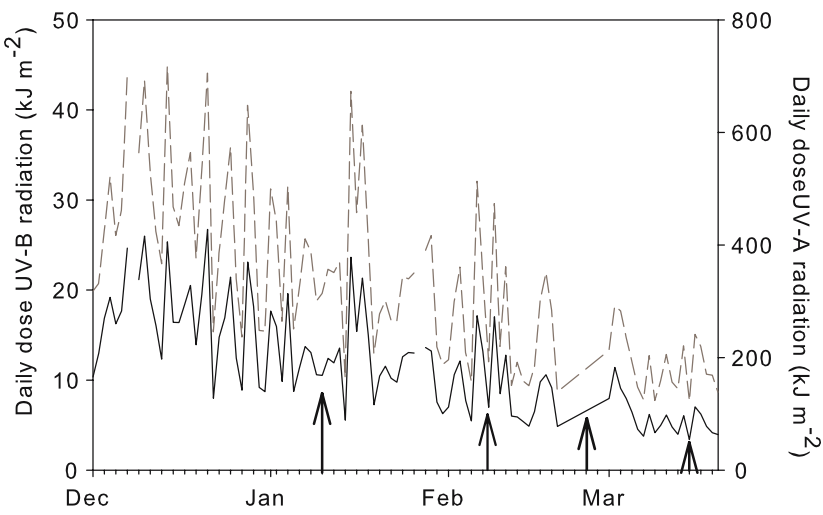

Fig. 2 Daily UV-A and UV-B doses from December 2004 to April 2005 measured at the Dallmann Laboratory (UV-A dashed grey line, UV-B black solid line). Arrows indicate the different sampling days 


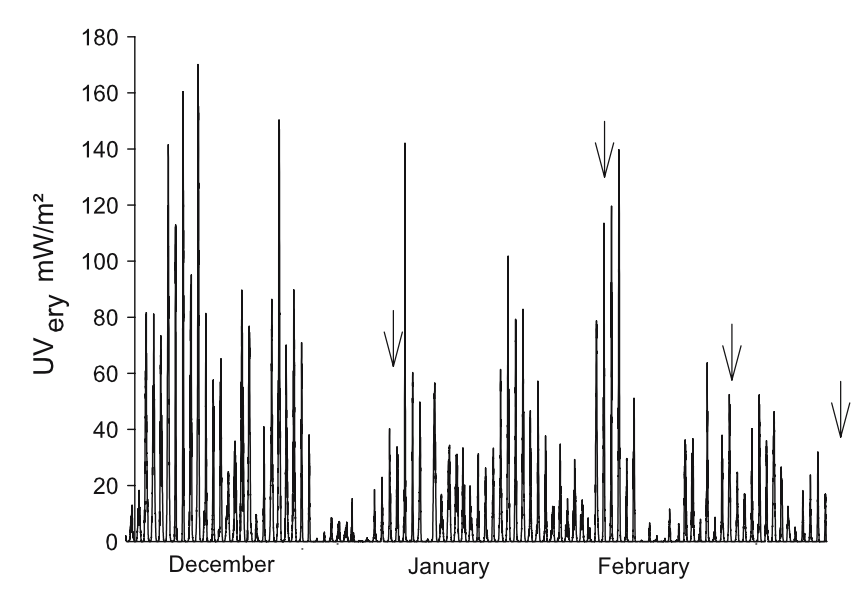

Fig. 3 Erythema weighted UV-B irradiance $\left(U_{\text {ery }}\right)$ during the duration of the experiment at Peñón Uno from December 2004 to March 2005. The sensor was located close to the cages with a maximal water column on top of $200 \mathrm{~cm}$ during high tide. Arrows indicate the different sampling days

Table 1 Minimal and maximal irradiance values at 10 and $200 \mathrm{~cm}$ water depth measured at the experimental site plus diffuse vertical attenuation coefficient of downward irradiance $\left(K_{\mathrm{d}}\right)$

\begin{tabular}{|c|c|c|c|c|c|c|c|}
\hline \multirow{2}{*}{$\overline{\text { Minimal values }}$} & \multirow{3}{*}{$\begin{array}{l}10 \mathrm{~cm} \\
200 \mathrm{~cm}\end{array}$} & \multicolumn{2}{|c|}{$\begin{array}{l}\text { PAR } \\
\left(\mu \mathrm{mol} \mathrm{m} \mathrm{m}^{-1}\right)\end{array}$} & \multicolumn{2}{|c|}{$\begin{array}{l}\text { UV-A } \\
\left(\mathrm{W} \mathrm{m}^{-2}\right)\end{array}$} & \multicolumn{2}{|c|}{$\begin{array}{l}\text { UV-B } \\
\left(\mathrm{W} \mathrm{m}^{-2}\right)\end{array}$} \\
\hline & & 360 & & 3 & & 0.16 & \\
\hline & & 100 & & 0.12 & & 0 & \\
\hline \multirow[t]{3}{*}{ Maximal values } & $10 \mathrm{~cm}$ & 1178 & & 26 & & 1.5 & \\
\hline & $200 \mathrm{~cm}$ & 513 & & 8.6 & & 0.26 & \\
\hline & & Mean & SD & Mean & SD & Mean & SD \\
\hline$K_{\mathrm{d}}$ & & 0.47 & 0.25 & 1.02 & 0.69 & 1.25 & 0.55 \\
\hline
\end{tabular}

All measurements $\pm 1 \mathrm{~h}$ around local noon for three solar wavebands: (1) PAR (400-700 nm, $n=7)$; (2) UV-A (320-400 nm, $n=12)$; (3) UV-B (280-320 nm, $n=12)$; measured with a broad-band sensor from December 2004 until February 2005

$t$ test $=2.78, P=0.032$; March: $t$ test $=3.66, P=0.011$ ), indicating cage artefacts. Furthermore, their density was significantly higher in closed cages in relation to open cages (January: $t$ test $=-3.30, P=0.003$; March: $t$ test $=$ $-4.66, P<0.001$, Table 2).

No UV effects on total grazer density were detected (RM ANOVA, radiation effect, $F_{2,18}=1.69, P=0.213$ ).

\section{Grazing and UVR effects}

Overall, few species settled on the tiles (Table 3). Dominant species were Navicula perminuta, Cocconeis costata and $C$. pennata.

In general, no significant differences between open and half cages, or between PAB and full sunlight treatments were detected for any of the tested parameters ( $t$ test,
Table 2 Grazer densities (number of individuals per cage) of the different grazer treatments (closed, open and half cage)

\begin{tabular}{|c|c|c|c|c|c|c|}
\hline & \multicolumn{2}{|c|}{$\begin{array}{l}\text { Closed cage } \\
(n=12)\end{array}$} & \multicolumn{2}{|c|}{$\begin{array}{l}\text { Open cage } \\
(n=12)\end{array}$} & \multicolumn{2}{|c|}{$\begin{array}{l}\text { Half cage } \\
(n=4)\end{array}$} \\
\hline & Mean & SE & Mean & SE & Mean & SE \\
\hline \multicolumn{7}{|l|}{ January } \\
\hline Nacella cocinna & 0 & 0 & 3.00 & 0.82 & 2.25 & 0.95 \\
\hline other Gastropods & 0.58 & 0.43 & 13.33 & 2.24 & 28.80 & 8.61 \\
\hline Amphipods & 28.75 & 3.15 & 14.58 & 2.92 & 22.50 & 4.79 \\
\hline \multicolumn{7}{|l|}{ March } \\
\hline Nacella cocinna & 0 & 0 & 1.67 & 0.47 & 3.25 & 1.03 \\
\hline other Gastropods & 2.58 & 0.74 & 2.67 & 0.58 & 3.50 & 1.89 \\
\hline Amphipods & 25.42 & 3.61 & 7.50 & 1.31 & 22.50 & 4.79 \\
\hline
\end{tabular}

Table 3 Species list for identified benthic diatoms on the tiles according to their abundance. Dominant $>50 \%$; frequent $=10-50 \%$; rare $=<5 \%$

\begin{tabular}{llc}
\hline Dominant & Frequent & Rare \\
\hline Navicula perminuta & Cocconeis costata var & Odontella sp. \\
& costata & \\
$\begin{array}{l}\text { Cocconeis costata var } \\
\text { antarctica }\end{array}$ & Navicula directa & Gyrosigma \\
Cocconeis pinnata & Licmophora gracilis & fasciola \\
& & Pleurosigma \\
& Licmophora antarctica & spalassiosira \\
& & sp. \\
& Licmophora sp. & Achnanthes \\
& & sp. \\
& Pseudogomphonema & Nitzschia \\
& kamtschaticum & distans \\
& Fragilariopsis sp. & Nitzschia \\
& & hybrida \\
& & Nitzschia sp. \\
& & Amphora sp. \\
& & Cocconeis \\
& schütti \\
& & Rhicospheria \\
& & sp. \\
\hline
\end{tabular}

$P>0.05)$, showing no cage or filter artefacts. There were two exceptions for the second and the last sampling date were cage artefacts were found ( $t$ test, Carbon content, $t=4.64, \quad P=0.003 ;$ abundance, $t=-4.62, \quad P=0.004$, respectively).

The most dominant diatom group throughout the experiment was the group of small naviculoid cells (mostly Navicula perminuta; Fig. 4). In the closed cages generally a significantly higher diatom abundance was found, from the second sampling date onwards (ANOVA: 2. sampling, $F=47.85, P<0.001 ; 3$. sampling, $F=22.10, P<0.001$; 
Fig. 4 Effects of UV

$(\mathrm{PAB}=\mathrm{PAR}+\mathrm{UV}-\mathrm{A}+$

UV-B, PA = PAR + UV-A,

$\mathrm{P}=\mathrm{PAR}$ ) and consumers (open and closed cages) on density of the most dominant diatoms groups and genus at the four sampling dates $(\mathbf{a}-\mathbf{d})$. Note that the first sampling has another scaling on the $y$-axis. Capitals indicate significant differences between consumer treatments. NAV Navicula sp., COC Cocconeis sp, LIC Licmophora sp., FRA Fragilariopsis sp.

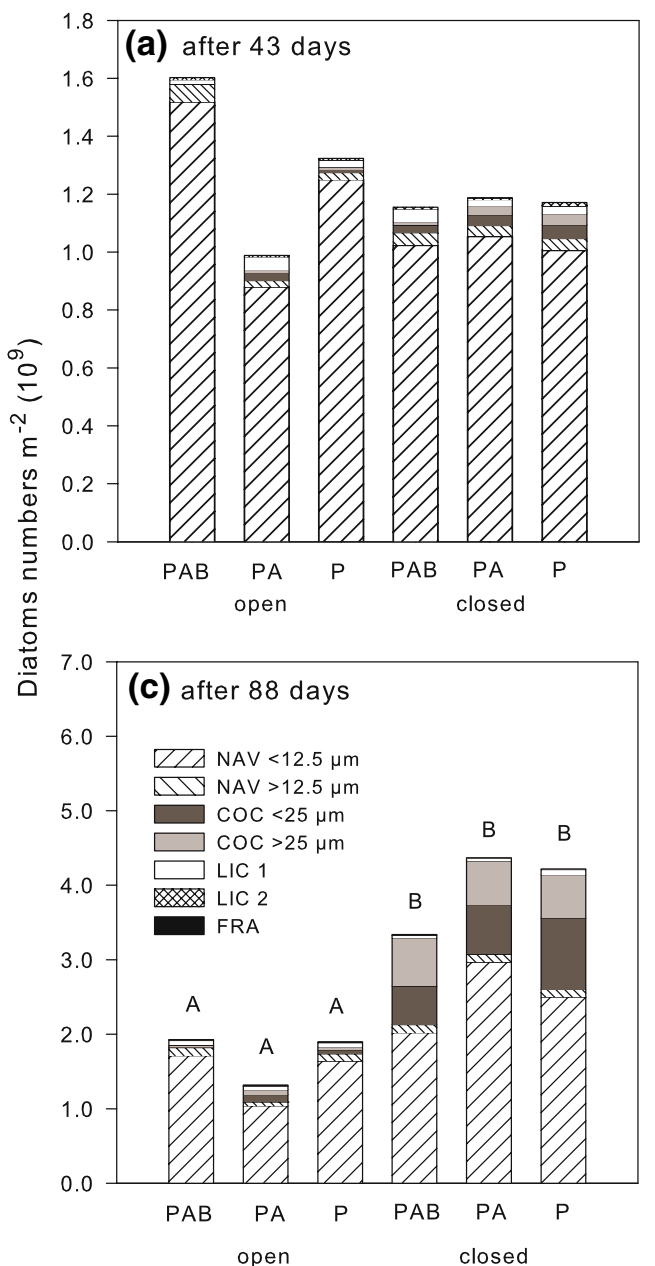

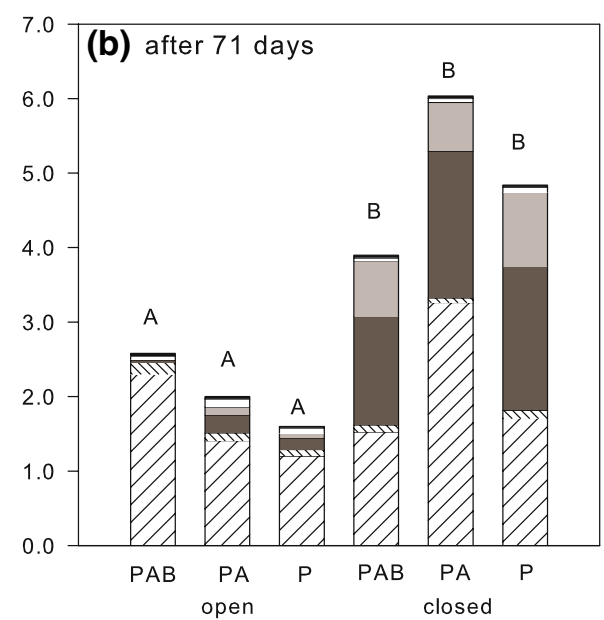

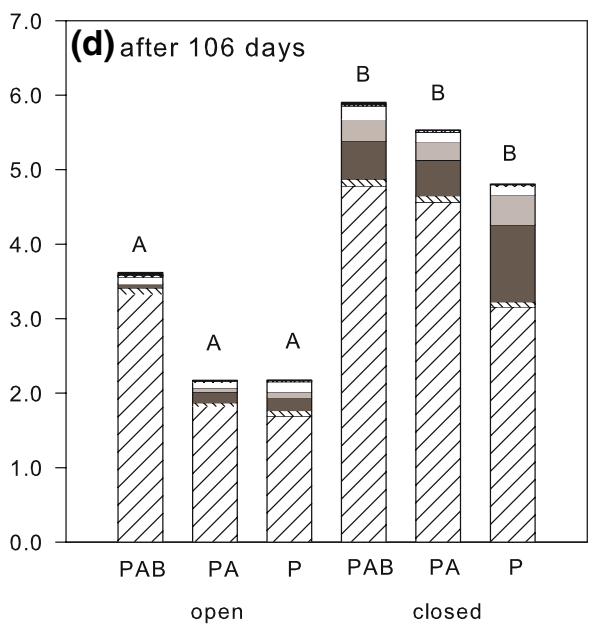

4. sampling, $F=28.20, P<0.001$; Fig. 4). In particular the density of small naviculoid cells, and cells of the genus Cocconeis increased. The genera Licmophora sp. and Fragilariopsis sp. were observed in almost all samples but were less abundant. No UV effects on the cell numbers were found.

Biomass was lowest at the first sampling date (Day 43), highest at the second (Day 71) and declined again until the last sampling date (Day 106, Fig. 5). In the closed cages, a significantly higher biomass was found from the second to the last sampling date (Kruskal - Wallis: 2. sampling, $H=17.28, P<0.001$; 3. sampling, $H=17.28, P<0.001$; ANOVA: 4. sampling, $F=72.05, P<0.001$; Fig. 5). Although the genus Cocconeis did not dominate in cell numbers this group prevailed in terms of biomass. No UV effects on biomass were observed.

Grazers significantly affected species composition at all sampling occasions with strongest effects found at the last three sampling dates (Table 4). SIMPER analysis showed that the naviculoid cells and Cocconeis together explained more than $90 \%$ of the dissimilarities between the open and closed cages. Thus, grazers decreased the diatom density in almost all cases (except from naviculoid cells at the first sampling date).

UVR had a significant effect on species composition at two sampling dates; PAB differed from PA (first sampling date) and $\mathrm{PAB}$ differed from $\mathrm{P}$ (fourth sampling date). The differences were mainly due to the increase in the numbers of the small naviculoid cells under the PAB treatments, explaining ca. $70 \%$ of the dissimilarity between the treatments (Table 4). However, average dissimilarity between these treatments was relatively low (17.75 and $32.53 \%$ at sampling date 1 and 4 , respectively).

\section{Discussion}

In the experimental area, the biomass of benthic diatoms was lower in the intertidal compared with the subtidal (Campana et al., unpublished), probably due to ice disturbance (e.g., spring), and high grazing pressure (e.g., summer). Overall, the experiments revealed strong significant grazing effects on the intertidal Antarctic microalgal assemblage. Negative UV effects could not be observed, 
Fig. 5 Effects of UV

$(\mathrm{PAB}=\mathrm{PAR}+\mathrm{UV}-\mathrm{A}+$

UV-B, PA = PAR + UV-A,

$\mathrm{P}=\mathrm{PAR}$ ) and consumers (open and closed cages) on biomass ( $\mathrm{g} \mathrm{C} \mathrm{m}^{-2}$ ) of the most dominant diatoms groups at the four sampling dates (a-d). Note that the first sampling has another scaling on the $y$-axis. Capitals indicate significant differences between consumer treatments. NAV Navicula sp., COC Cocconeis sp., LIC Licmophora sp., FRA Fragilariopsis sp.
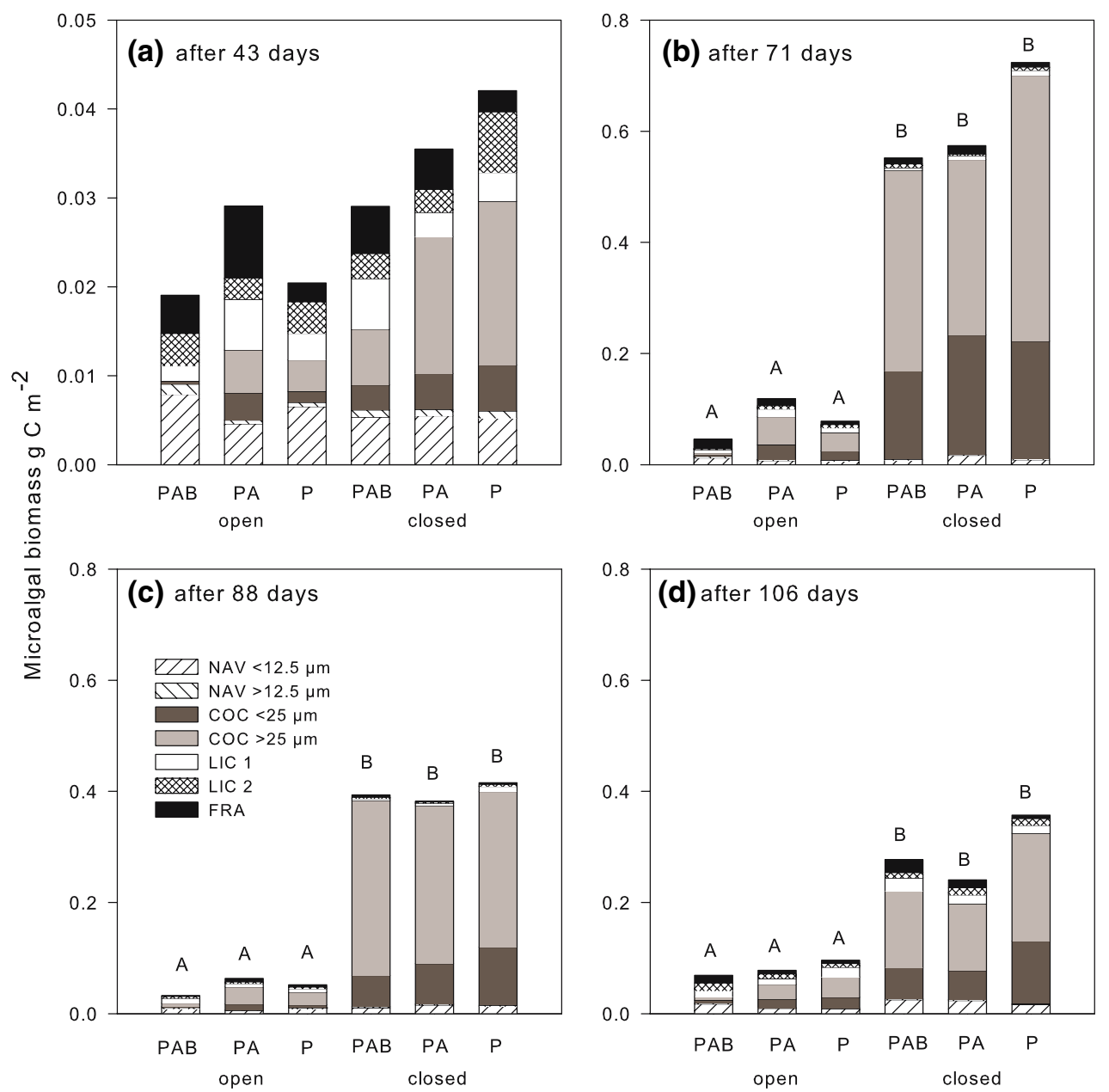

indicating efficient adaptation and/or acclimation processes of the microphytobenthic assemblage. However, some positive UV effects were found on small naviculoid cells.

Methodological considerations

In our experiment, as observed by others (e.g., Hillebrand et al. 2000), some inconsistent cage artefacts were found; a higher biomass but a lower abundance in half cages compared with open ones at the second and forth sampling, respectively. These findings are most likely a consequence of the high natural variability in these types of fieldexperiments. Nevertheless, we believe, that field-experiments on community level, like ours, still give valuable insights to complex ecological interactions, impossible to test in the laboratory. Meiofauna can have a grazing impact on benthic microalgae but they were not included in our experimental design, however, only very few e.g., copepods or polychaets were observed. Therefore, it is likely that their impact in relation to the grazing impact by macrograzers was negligible.
Grazing effects

From 71 days onwards, grazing significantly reduced benthic diatom biomass and altered the species composition. These findings are in agreement with previous studies on benthic diatoms from marine (e.g., Hillebrand et al. 2000), and freshwater (Steinman 1996; Hill et al. 1997), habitats. In our study, the absence of grazers generally favoured the abundance of the diatom genus Cocconeis. One reason for a lack of grazer effects at the first sampling was therefore, due to very few Cocconeis individuals during early succession. Another reason is the low biomass in general. Grazers were shown to be ineffective in low biomass environments (Hillebrand et al. 2000). In contrast to other studies, grazers were not affected by UV radiation in our study (Bothwell et al. 1994).

The reduced diatom biomass was not caused by amphipods (not excluded from the closed cages). Many Antarctic amphipods e.g., Gondogeneia antarctica are omnivorus and feed on microalgae (Jazdzewski et al. 2001), but they might have difficulties to graze on firmly 
Table 4 Results of ANOSIM (pairwise test and Global R, $P$ ) on species composition for all sampling events, and results of SIMPER for significant results, indicating the contribution of single species to total dissimilarity in species composition due to treatment effects

\begin{tabular}{|c|c|c|c|}
\hline & $U V$ PAB:P & $U V P A B: P A$ & Grazing \\
\hline After 43 days & $\mathrm{R}=0.198, P=0.078$ & $\mathrm{R}=0.260, P=0.003$ & $\mathrm{R}=\mathbf{0 . 3 8 2}, P=0.001$ \\
\hline$N A V<12.5 \mu m$ & $\mathrm{Nt}$ & $73.14 \%+$ & $70.18 \%+$ \\
\hline$C O C<25 \mu m$ & $\mathrm{Nt}$ & $<10.0 \%$ & $<10.0 \%-$ \\
\hline$C O C>25 \mu m$ & $\mathrm{Nt}$ & l & $<10.0 \%-$ \\
\hline After 71 days & $\mathrm{R}=0.307, P=0.037$ & $\mathrm{R}=0.328, P=0.018$ & $\mathrm{R}=0.990, P=0.001$ \\
\hline$N A V<12.5 \mu \mathrm{m}$ & $\mathrm{Nt}$ & $\mathrm{Nt}$ & $28.71 \%-$ \\
\hline$C O C<25 \mu m$ & $\mathrm{Nt}$ & $\mathrm{Nt}$ & $46.50 \%-$ \\
\hline$C O C>25 \mu m$ & $\mathrm{Nt}$ & $\mathrm{Nt}$ & $20.43 \%-$ \\
\hline After 88 days & $\mathrm{R}=-0.016, P=4.91$ & $\mathrm{R}=0.281, P=0.033$ & $\mathrm{R}=0.931, P<0.001$ \\
\hline$N A V<12.5 \mu m$ & $\mathrm{Nt}$ & $\mathrm{Nt}$ & $46.67 \%-$ \\
\hline$C O C<25 \mu m$ & $\mathrm{Nt}$ & $\mathrm{Nt}$ & $26.11 \%-$ \\
\hline$C O C>25 \mu m$ & $\mathrm{Nt}$ & $\mathrm{Nt}$ & $22.18 \%-$ \\
\hline After 106 days & $\mathrm{R}=0.422, P=0.002$ & $\mathrm{R}=0.266, P=0.082$ & $\mathrm{R}=0.792, P<0.001$ \\
\hline$N A V<12.5 \mu \mathrm{m}$ & $67.16 \%+$ & $\mathrm{Nt}$ & $66.09 \%-$ \\
\hline$C O C<25 \mu m$ & $18.14 \%-$ & $\mathrm{Nt}$ & $19.10 \%-$ \\
\hline$C O C>25 \mu m$ & $<10.0 \%$ & $\mathrm{Nt}$ & $<10.0 \%-$ \\
\hline
\end{tabular}

Data were square root transformed, PAB $=$ PAR + UV-A + UV-B, PA $=$ PAR + UV-A, P $=$ PAR; Nt $=$ not tested. The direction of the effect is given as + positive UV or consumer effect, -negative UV (-B) or grazing effect. Significant results are bold

NAV Navicula sp., COC Cocconeis sp.

attached diatoms. The latter was confirmed by our results where the biomass in closed cages was higher than in open ones although amphipods were present. The firm attachment of the diatoms was further emphasised by our difficulties to detach the cells from the tiles during sampling. In support of our results, Sommer (2000 and references therein), showed that a tight attachment to the substratum offered protection against grazing by the isopod Idothea chelipes. Furthermore, Hillebrand et al. (2000 and references therein), found an herbivore preference of erect, chain-building microalgal species over more attached species such as Cocconeis sp. and, moreover, diatoms might be more accessible for grazers when growing as epiphytes on macroalgae. In this context, the impact of amphipods on the microalgal assemblage growing in our experiment seems to be negligible. Consequently, biomass effects were mainly caused by larger gastropods, e.g., Nacella concinna, successfully excluded by cages. This limpet is clearly the largest (mean length $20-30 \mathrm{~mm}$ ) and most important grazer at our study site and can reach densities from 28 to 131 ind. $\mathrm{m}^{-2}$ in the Antarctic intertidal (Brêthes et al. 1994). Nacella concinna feeds on macroalgal propagules and benthic microalgae (Iken 1996; Kim 2001; Peck and Veal 2001). Due to the availability of important energy resources in form of benthic micro- and macroalgae, Nacella migrates to the intertidal in spring (Brêthes et al. 1994). In winter it migrates back into the subtidal zone. The abundance of microphytobenthos is correlated with the soma and gonad mass of Nacella (Brêthes et al. 1994), which further demonstrates the important trophic link between microphytobenthos and this limpet.

In the absence of gut analysis and other direct measurements, selectivity of grazers for different algal species or growth types can only be inferred from the species composition of the prey community. Herbivores can alter species composition by actively preferring food items (active choice), by passively ingesting more of the species which are structurally more available (passive preference), or by changing the competitive outcome between prey species by increasing mortality rates or nutrient supply via regeneration (Hillebrand et al. 2000).

In our study, species composition was mainly shaped by the consumption of small diatoms belonging to the genera Navicula and Cocconeis (open cages). A selective choice of the main grazer $N$. concinna and other, smaller gastropods is most unlikely because they feed on all algae available (as shown by their feeding track). Usually herbivores are known to prefer loosely attached, upperstory microalgae (Hillebrand et al. 2000). However, such algae did not grow in our experiment and grazers like $N$. concinna were apparently successful in removing firmly attached diatoms. Therefore, we conclude that gastropods can act as important drivers on community structure in the Antarctic intertidal during microalgal succession. 


\section{UV effects}

The relative increase in UV-B radiation over the last 25 years has been highest in Antarctica compared with other regions of the world. Thus, any UV effects on benthic diatoms should most likely be found here (particularly in the intertidal). However, the lack of UV effects found on biomass and abundance of benthic Antarctic diatoms confirmed former studies at different geographical sites (e.g., Hill et al. 1997). Earlier field-studies on UV effects on benthic microalgae have mainly focussed on soft bottom communities where benthic diatoms seem to be very tolerant to UV-B radiation (Peletier 1996; Wulff 1999 and references therein). The main variable to some extent affected in these communities was primary productivity while structural variables such as the overall biomass and microalgal pigments appeared unaffected (Odmark et al. 1998; Sundbäck et al. 1997; Wulff et al. 1999; Wulff et al. 2000). Wulff (1999), hypothesized that the lack of UV effects on structural variables in earlier field-experiments was due to the study of already established diatom communities and inadequate (too short) experimental periods. Microbenthic assemblages during early succession, as in our study, should therefore be more UV susceptible (Wulff et al. 2000). Nevertheless, no UV effects were found on any of the tested structural variables during the 3.5 month sampling period. It should be pointed out, however, in a few studies transient UV effects on e.g., biomass and species composition have been found in an early stage of microalgal succession (Santas et al. 1998; Wulff et al. 2000). The authors related these effects to a species-specific response to UV-B radiation. Particularly Navicula perminuta, the most common species in our study, was shown to adapt and recover rapidly from UV-B induced stress (Waring et al. 2006). A habitat-specific effect of UV radiation on microphytobenthic communities was described by Villafañe et al. (2003). However, in this review UV-B was expected to be a more important controlling factor in cold climate habitat in relation to habitats in lower latitudes due to more frequent colonization effects (ice and scouring). Our findings are in contradiction to this study showing that hard bottom intertidal microphytobenthos in Antarctica was unaffected by UV radiation for the tested parameter.

\section{Interactive grazing and $\mathrm{UV}$ effects}

Interactions between UV radiation and consumers can e.g., occur when UV induces changes in the chemical composition of the algae, thereby altering consumption patterns (Lotze et al. 2002). On the other hand, UV radiation can have a direct negative effect on the grazers, resulting in an enhanced algal productivity (Bothwell et al. 1994).
However, no grazer - UV interactions were found in our study for the four sampling occasions as also observed by Hill et al. (1997). No direct affect of UV radiation on the grazers occurring in the sampling area were detected.

In conclusion, the intertidal benthic diatoms were found to be an important food source for the Antarctic gastropod community. With respect to UV radiation the benthic diatoms were unaffected. However, only few species were found in the intertidal, only the ones best adapted for this extreme environment (species-specific UV effects). From an evolutionary perspective, it might be that these species have a capacity to endure UV-B radiation. During the course of evolution, they have been exposed to high irradiance levels and UV radiation exerted a selective pressure. Therefore, it is plausible that the cause of this "endurance" is due to not yet established key mechanisms.

Acknowledgments This work has been done under the agreement on scientific cooperation between the Alfred Wegener Institute and the Dirección Nacional del Antárctico at Dallmann Laboratory, annex to Jubany station. The authors thank the German and the Argentine dive crews of Jubany and Dallmann for assistance in the field. Special thanks to Dr. A. Al-Handal for diatom identification. We gratefully acknowledge financial support by the foundations of YMER, KVVS, Lennander, Längmanska and Helge Ax:son Johnson, the Swedish Institute, the German Research Council (DFG), and the Alfred Wegener Institute for Polar and Marine Research, Germany.

\section{References}

Ahn IY, Chung H, Kang JS, Kang SH (1994) Preliminary studies on the ecology of neritic marine diatoms in Maxwell Bay, King George Island, Antarctica. Korean J Phycol 9:37-45

Blanchard GF, Gall VCL (1994) Photosynthetic characteristics of microphytobenthos in Marennes-Oleron Bay, France: preliminary results. J Exp Mar Biol Ecol 182:1-14

Bothwell ML, Sherbot DMJ, Pollock CM (1994) Ecosystem response to solar ultraviolet-B radiation: Influence of trophic-level interactions. Science 265:97-100

Brêthes J-C, Ferreyra G, de la Vega S (1994) Distribution, growth and reproduction of the limpet Nacella (Patinigera) concinna (Strebel 1908) in relation to the potential food availability, in Esperanza Bay (Antarctic Peninsula). Polar Biol 14:161-170

Cahoon LB (1999) The role of benthic microlagae in neritic ecosystems. Oceanogr Mar Biol Annu Rev 37:47-86

Edler L (1979) Recommendation on methods for marine biological studies in the Baltic Sea. Phytoplankton and chlorophyll. Baltic Marine Biologists Publication, Gotab, Malmö, p 1-38

El Naggar S, Gustat H, Magister H, Rochlitzer R (1995) An electronic personal UV-B dosimeter. J Photochem Photobiol B 31:83-86

Gilbert NS (1991a) Microphytobenthos seasonality in near-shore marine sediments at Signy Island, South Orkney Islands, Antarctica. Est Coast Shelf Sci 33:89-104

Gilbert NS (1991b) Primary production by benthic microlagae in nearshore marine sediments of Signy Island, Antarctica. Polar Biol 11:339-346

Glud RN, Risgaard-Petersen N, Thamdrup B, Fossing H, Rysgaard S (2000) Benthic carbon mineralization in a high-arctic sound. Mar Ecol Prog Ser 206:59-71 
Hapter R, Wozniak B, Dobrowolski K (1983) Primary production in Ezcurra inlet during the Antarctic summer of 1997/98. Oceanologia 15:175-184

Hendey NI (1952) Littoral diatoms of Chichester Harbour with special reference to fouling. J R Micrsc Soc 71:1-86

Hendey NI (1964) An introductory account of the smaller algae of the British coastal waters, 5. Bacillariophyceae (Diatoms). Fishery Inv. Ser. 4, London

Hill W, Dimick SM, McNamara A, Brabsons CA (1997) No effects of ambient UV radiation detected in periphyton and grazers. Limnol Oceanogr 42:769-774

Hillebrand H, Worm B, Lotze HK (2000) Marine microbenthic community structure regulated by nitrogen loading and grazing pressure. Mar Ecol Prog Ser 204:27-38

Hillebrand H, Durselen CD, Kirschtel D, Pollingher U, Zohary T (1999) Biovolume calculation for Pelagic and Benthic microalgae. J Phycol 35:403-424

Hustedt F (1961-1966) Die Kieselalgen Deutschlands, Österreich und der Schweiz unter Berücksichtigung der übrigen Länder Europas sowie der angrenzenden Meeresgebiete. Dr L. Rabenhorsts Kryptogamen-Flora, Band VII, Teil 2. Akademische Verlagsgesellschaft, Leipzig

Iken K (1996) Trophische Beziehungen zwischen Makroalgen und Herbivoren in der Potter Cove. Ber Polarforsch Meeresforsch 201

Jazdzewski K, Broyer Cd, Pudlarz M, Zielinski D (2001) Seasonal fluctuations of vagile benthos in the uppermost sublittoral of a maritime Antarctic fjord. Polar Biol 24:910-917

Kim D (2001) Seasonality of marine algae and grazers of an Antarctic rocky intertidal, with emphasis on the role of the limpet Nacella concinna Strebel (Gastropoda: Patellidae). Ber Polarforsch Meeresforsch 397

Kirk JTO (1994) Light and Photosynthesis in Aquatic Ecosystems. Cambridge University Press

Krammer K, Lange-Bertalot H (1986) Süßwasserflora von Mitteleuropa 1 Teil: Naviculaceae. Gustav Fischer Verlag, Stuttgart New York

Krammer K, Lange-Bertalot H (1988) Süßwasserflora von Mitteleuropa 2. Teil: Bacillariaceae, Epithemiaceae, Surirellaceae. Gustav Fischer Verlag, Stuttgart New York

Lotze HK, Worm B, Molis M, Wahl M (2002) Effects of UV radiation and consumers on recruitment and succession of a marine macrobenthic community. Mar Ecol Prog Ser 243:57-66

Odmark S, Wulff A, Wängberg SA, Nilsson C, Sundbäck K (1998) Effects of UVB radiation in a microbenthic community of a marine shallow-water sandy sediment . Mar Biol 132:335-345

Peck LS, Veal R (2001) Feeding, metabolism and growth in the Antarctic limpet, Nacella concinna (Strebel 1908). Mar Biol 138:553-560

Peletier H (1996) Long-term changes in intertidal estuarine diatom assemblages related to reduced input of organic waste. Mar Ecol Prog Ser 137:265-271

Polis GA, Strong DR (1996) Food web complexity and community dynamics. Am Nat 147:813-846

Quinn GP, Keough MJ (2004) Experimental Design and Data Analysis for Biologists. Cambridge University Press

Round FE, Crawford RM, Mann DG (1990) The Diatoms: biology and morphology of the genera. Cambridge University Press, Cambridge

Rysgaard S, Nielsen TG, Hansen BW (1999) Seasonal variation in nutrients, pelagic primary production and grazing in a high-
Arctic coastal marine ecosystem, Young Sound, Northeast Greenland. Mar Ecol Prog Ser 179:13-25

Rysgaard S, Kühl M, Glud RN, Würgler Hansen J (2001) Biomass, production and horizontal patchiness of sea ice algae in a highArctic fjord (Young Sound, NE Greenland). Mar Ecol Prog Ser 223:15-26

Santas R, Santas Ph, Lianou Ch, Korda A (1998) Community responses to UV radiation. II. Effects of solar UVB on field-grown diatom assemblages of the Caribbean. Mar Biol 131:163-171

Schloss IR, Ferreyra GA, Curtosi CUR (1998) Phytoplankton primary production in Potter Cove, King George Island. Ber Polarforsch Meeresforsch 299. Bremerhaven

Schloss IR, Ferreyra GA, Ruiz-Pino D (2002) Phytoplankton biomass in Antarctic shelf zones: a conceptual model based on Potter Cove, King George Island. J Mar Syst 36:129-143

Sommer U (2000) Benthic microalgal diversity enhanced by spatial heterogeneity of grazing. Oecologia 122:284-287

Steinman AD (1996) Effects of grazers on benthic freshwater algae. In: Stevenson RJ, Bothwell ML, Lowe RL (eds) Algal ecology freshwater benthic ecosystems. Academic Press, San Diego, pp 341-373

Sundbäck K, Odmark S, Wulff A, Nilsson C, Wängberg SA (1997) Effects of enhanced UVB radiation on a marine benthic diatom mat. Mar Biol 128:171-179

Underwood GJC, Nilson C, Sundbäck K, Wulff A (1999) Short-term effects of UVB radiation on chlorophyll fluorescence, biomass, pigments and carbohydrate fractions in a benthic diatom mat. $\mathrm{J}$ Phycol 35:656-666

Villafañe V, Sundbäck K, Figueroa F, Helbling W (2003) Photosynthesis in the aquatic environment as affected by UVR. In: Helbling W, Zagarese $\mathrm{H}$ (eds.) UV effects in aquatic organisms and ecosystems, comprehensive series in photochemical and photobiological sciences. vol 1, Roy Soc Chem, Cambridge

Wahl M, Molis M, Davis A, Dobretsov S, Dürr ST, Johansson J, Kinley J, Kirugara D, Langer M, Lotze HK, Thiel M, Thomason JC, Worm B, Zeevi Ben-Yosef D (2004) UV effects that come and go: a global comparison of marine benthic community level impacts. Glob Change Biol 10:1962-1972

Waring J, Underwood GJC, Baker NR (2006) Impact of elevated UV$\mathrm{B}$ radiation on photosynthetic electron transport, primary productivity and carbon allocation in estuarine epipelic diatoms. Plant Cell Environ 29:521-534

Weatherhead EC, Andersen SB (2006) The search for signs of recovery of the ozone layer. Nature 441:39-45

Witkowski A, Lange-Bertalot H, Metzelin D (2000) Diatom flora of Marine Coasts I. Iconographia Diatomologica 7. Gantner Verlag K.G., Germany

Wulff A (1999) Microbenthic communities in a changing light environment with emphasis on UVB radiation. Ph.D thesis ISBN 91-88896-17-X, University of Göteborg, Sweden

Wulff A, Nilsson C, Sundbäck K, Wängberg S-A, Odmark S (1999) UV radiation effects on microbenthos: a four month field experiment. Aquat Microb Ecol 19:269-278

Wulff A, Wängberg SA, Sundbäck K, Nilsson C, Underwood GJC (2000) Effects of UVB radiation on a marine microphytobenthic community growing on a sand-substratum under different nutrient conditions. Limnol Oceanogr 45:1144-1152

Zacher K, Wulff A, Molis M, Hanelt D, Wiencke C (2007) UV radiation and consumer effects on a field-grown intertidal macroalgal assemblage in Antarctica. Glob Change Biol (in press) 